\title{
Nutritional Compositions of Shelf Stable Maize Starch and Defatted Beniseed (Sesame indicum) Meal Blends
}

\author{
Anuonye JC ${ }^{1}$, Joshua ${ }^{1}$, Chimma $\mathrm{CE}^{\mathbf{1}}$ and Wada $\mathrm{AC}^{2 *}$ \\ ${ }^{1}$ Department of Food Science and Technology, Federal University of Technology, Minna, Nigeria \\ ${ }^{2}$ National Cereals Research Institute, Badeggi Bida, Niger State, Nigeria \\ *Corresponding Author: Wada AC, National Cereals Research Institute, Badeggi Bida, Niger State, Nigeria.
}

Received: September 16, 2019; Published: October 10, 2019

DOI: $10.31080 /$ ASNH.2019.03.0484

\begin{abstract}
Sourcing for cereals and legumes/oil seeds whose complementation yields high energy- protein density meals for both infant and adylt nutrition continues as several complemented blends recorded low energy and poor amino acids score, while some recorded very high fibre content with low mineral composition. However, at present there exists no information on the nutritional compositioh of shelf stable maize starch fortified with defatted beniseed meal. The present work was, therefore, set up to provide base line information on fortified shelf stable maize starch with defatted beniseed meal. Composite flour was produced from shelf stable maize starch and defatted beniseed meal. Dehulling and partial defatting were carried out using hexane as solvent and hand pressing methods. The shelf stable maize starch and partially defatted beniseed meal were then used in composite formulation at ratios of 87.50:12.50, 75:25, 67.50:37.50 and 50:50 of maize starch to beniseed meal respectively. Appropriate profile and antinutrient levels of the blends and their acceptability were also evaluated. Results show that protein values, fat and fibre contents significantly increased from $12.6-64.8 \%, 9.4-65.5 \%, 54.7-74.8 \%$ and 28.8 - 61.9\% respectively for solvent and manual extraction methods, while carbohydrate content of the meals decreased from between $41.1-17.7 \%$ and $32.87-99.8 \%$ respectively for the two methods. The protein content of the samples fortified with chemically defatted sesame meal significantly $(\mathrm{P}<0.05)$ increased from $5.70-15.67 \%$, while their fat content increased from $6.00-15.67 \%$. Similar results were obtained from samples fortified with the hand pressed defatted sesame meal with increased protein content from 5.70 to $15.57 \%$ and fat content from $6.0-26.7 \%$. There were also slight increases in the mineral composition with Phosphorus increasing from 0.37 to 0.40 and 0.43 respectively in both manual and solvent extracted samples. Significant $(\mathrm{P} \leq 0.05)$ increase in high quality amnio acids of up to $37.5 \%$ and low microbial count were recorded with the addition of defatted sesame meal flour thus making it adequate for use as infant and adult nutrition irrespective of the extracting method.
\end{abstract}

Keywords: Beniseed or Sesame; Infant and Adult Nutrition; Maize Starch; Nutrient and Anti Nutrient Composition; Partially Defatted Beniseed Meal; Shelf Stable

\section{Introduction}

'Ogi' or pap is a cereal generic name for semi solid foods made from cereal starch. It is the most popular cereal meal for many homes [1] used for weaning, breakfast and convenient meal in $\mathrm{Ni}$ geria. Medical personnel do recommend it for sick people because it is light in the stomach and easy to digest. Statistics show that about one -third of the total population of Nigeria consumes ogi at least once a week (Steinkraus, 2002). However considerable nutrient losses resulting in a condition known as kwashiorkor take place during such processing steps as steeping, milling, and sieving among infants [2]. It also has the problem of shelf keeping at ambient temperature $(25+50 \mathrm{o})$ due to its high moisture content. Anuonye [3] reported a technology for the preparation of shelf stable cereal starch for ogi, while Egounlety., et al. [4] reported that protein could be increased from $1.4 \%$ to $13 \%$ in germinated and fortified preparation while amino acids like lysine could increase up to more than $50 \%$ when cowpea is added.

Uwala [5] reported that the development of defatted beniseed flour can provide industry with new high protein food ingredients for products formulation and protein fortification since sesame contains $3.2 \%$ methionine which is often the limiting amino acid in legume-based tropical diets. It is therefore an important source of high quality protein for supplementation of other crops such as peanut, soybean and other legumes of tropical diets.

The search for suitable plant sources of protein for substitution of animal sources will continue especially for less developed nations. Several reports by Jeanne., et al. [6], Theoblad and Mary 
[7], Eugenie., et al. [8] and Bintu., et al. [9] showed that there is still need for sourcing such cereals and legumes/oil seeds whose complementation will yield high energy- protein density meals that will meet standard recommendations for both infant and adult nutrition. The reports showed that the complemented blends had the problem of low energy and poor chemical score of their amino acids while some had very high fiber content with low mineral composition.

There is currently no information on the nutritional composition of shelf stable maize starch fortified with defatted beniseed meal in Nigeria. The present work was, therefore, set up to provide base line information on fortified shelf stable cereal starches particularly maize starch with defatted beniseed meal with the view to determining the proximate and mineral composition of blends of shelf stable maize starch and defatted beniseed meal. In addition to determine the amino acid profile and protein quality of raw and blended samples of the shelf stable maize starch and defatted beniseed meal and to determine some anti- nutrients of the blends.

\section{Materials and Methods}

Sesame seed variety NCRI BEN 04-2E was obtained from the National Cereals Research Institute (NCRI) Badeggi, Niger- state Nigeria. Maize grain was purchased from Kure Central Market in Minna Metropolis, Nigeria.

\section{Sesame seed processing and defatting}

Dehulling, roasting and partial defatting using the hand press extraction method was carried out as reported by Anounye., et al. [10].

\section{Solvent extraction}

The method reported by Nwabueze and Iwe [11] was adopted for partial sesame oil extraction using hexane as solvent.

Preparation of starch/blending with partially defatted beniseed meal

The method reported by Anuonye [3], figure 1 was used in the preparation of shelf stable white maize starch and subsequent complementation with defatted beniseed meal.

Formulation of blends

The substitution of defatted beniseed flour meal by hand pressed or solvent extraction method was carried out as reported by Anuonye [12] table 1.

\section{Analysis}

The proximate composition of raw and blended samples was evaluated as reported in the official methods of Analysis AOAC [13]. Parameters evaluated include protein, fat, moisture, crude fibre, ash and carbohydrate was quantified by the difference.

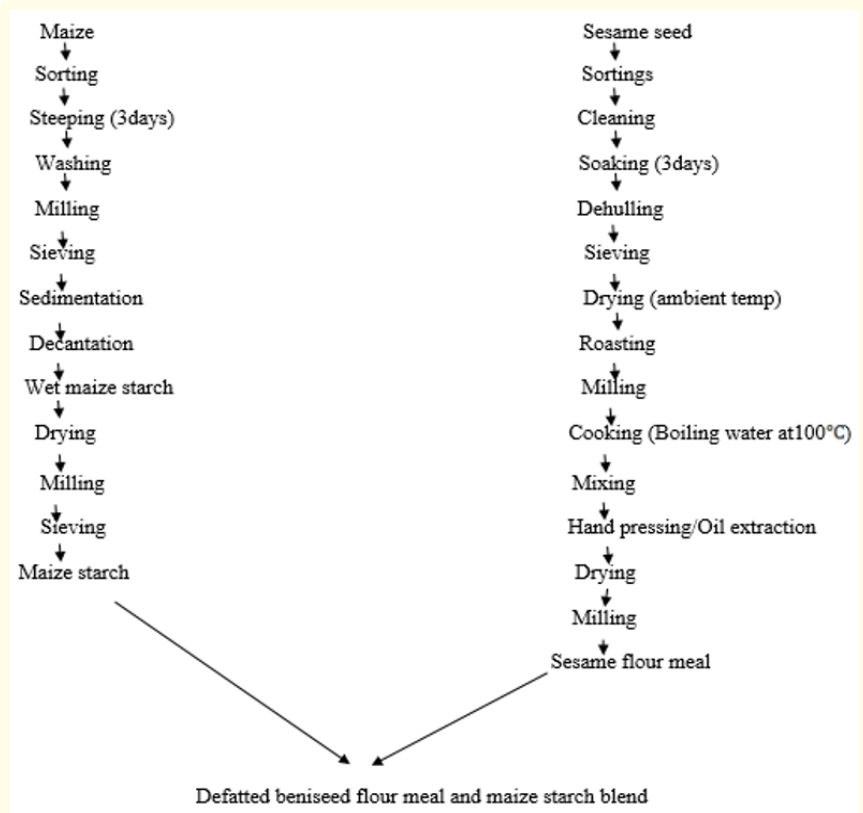

Figure 1: Flow Chart showing the technology for producing shelf stable maize starch and defatted beniseed blends (Anuonye, 2012).

\begin{tabular}{|l|c|c|}
\hline \multicolumn{1}{|c|}{ Blend code } & Maize & Defatted beniseed \\
\hline A & $100 \%$ & $0 \%$ \\
\hline B & $87.5 \%$ & $12.5 \%$ \\
\hline C & $75 \%$ & $25 \%$ \\
\hline D & $62.5 \%$ & $37.5 \%$ \\
\hline E & $50 \%$ & $50 \%$ \\
\hline
\end{tabular}

Table 1: Levels of substitution of defatted beniseed flour meal in maize starch.

Source: Anuonye, (2006)

Determination for minerals

The mineral composition of the blends was evaluated using an Atomic Absorption Spectrophotometer (Buck 210 VGP Germany) according to AOAC [13] for $\mathrm{P}, \mathrm{K}, \mathrm{Na}, \mathrm{Mg}$ and $\mathrm{Ca}$.

\section{Determination of amino acid}

The amino acid profile (AAP) was evaluated at the Zoology Department of the University of Jos using Sequential Multi-Analyser Technicon (TSM-1 Model DNA 0209) as described by Spackman., et al. [14]. The samples were dried to constant weight, defatted, hydrolysed and evaporated in a rotary evaporator and then loaded into the analyzer. The amounts loaded were between 5-10 micro litres and were dispensed into the cartridge of the analyzer. They were then separated and analysed as free acidic and basic amino acids. The period of analysis lasted 76 minutes and the Amino acid content calculated as $\mathrm{g} / 100 \mathrm{~g}$ protein and computed by measuring the net height of each amino acid produced by the chart recorder. 


\section{Analysis of anti-nutritional components}

The antinutrients including oxalate, phytate as phyticic acid, and tannin were evaluated according to AOAC [13].

\section{Sensory evaluation}

The blends were made into semi solid gel in an aluminum pot using $100 \mathrm{ml}$ of clean tap water with $100 \mathrm{~g}$ of each blend made into a paste. The water was heated to $100^{\circ} \mathrm{C}$ after which the paste was poured into the boiling water and the mixture continuously stirred for 5 minutes to obtain a semi-solid gel and proper doneness. Blends of defatted beniseed meal and maize starch were provided in coded white plastic plates and the resulting $100 \%$ maize porridge or pap served as the control. The order of presentation of samples to the panel was randomized and tap water was provided to each panelist to rinse their mouths in between each taste. The samples were evaluated for appearance, aroma, colour, evenness, taste, texture and overall acceptability. Each sensory attribute was rated on a 9-point hedonic scale where, 1 represented disliked extremely and 9 liked extremely as described by Larmond (1977).

\section{Statistical analysis}

The data obtained were subjected to analysis of variance (ANO$\mathrm{VA})$ and means of significant values accepted at $(\mathrm{P}>0.05)$ were separated by Duncan's Multiple Range test at ( $\mathrm{p}<0.05)$ using SPSS (Statistical Package for Social Scientist) version 16.0.

\section{Results and Discussion}

Proximate composition

Results presented in Tables 2 and 3 show the proximate composition of the Blends of the shelf stable maize starch and partially defatted beniseed meal extracted by the solvent and hand extraction methods for protein, fat, ash, carbohydrate and energy which increased significantly from 12.6-64.8\%, 9.4-65.5\%, 54.7-74.8\% and $28.8-61.9 \%$ respectively for solvent extraction and for manual extraction methods with concomitant decrease of carbohydrate from $41.1-17.7 \%$ for solvent extraction and $32.87-9.8 \%$ for hand pressed methods respectively. The defatting process which is more of a concentration process as suggested by Eugenie., et al. [8] led to increases in the protein content of the meals. The addition of partially defatted beniseed meals to the maize starch led to significant $(\mathrm{P}<0.05)$ increases in the protein content of the resulting blends. The protein increase was from $16.74-65 \%$ for both solvent defatting and hand pressed defatting methods.

\begin{tabular}{|l|c|c|c|c|c|}
\hline \multicolumn{1}{|c|}{ Parameters } & A & B & C & D & E \\
\hline Protein $(\mathrm{g} / 100 \mathrm{~g})$ & $5.47 \pm 0.20$ & $6.83 \pm 0.02$ & $9.50 \pm 0.20$ & $10.63 \pm 0.04$ & $15.53 \pm 0.10$ \\
\hline Fat $(\mathrm{g} / 100 \mathrm{~g})$ & $6.01 \pm 0.20$ & $9.19 \pm 0.20$ & $15.19 \pm 0.20$ & $19.64 \pm 0.04$ & $23.79 \pm 0.20$ \\
\hline Fibre $(\mathrm{g} / 100)$ & $1.82 \pm 0.02$ & $2.64 \pm 0.02$ & $4.40 \pm 0.10$ & $4.51 \pm 0.10$ & $4.87 \pm 0.02$ \\
\hline Ash $(\mathrm{g} / 100 \mathrm{~g})$ & $0.62 \pm 0.10$ & $0.78 \pm 0.10$ & $1.20 \pm 0.10$ & $1.74 \pm 0.20$ & $2.07 \pm 0.10$ \\
\hline CHO $(\mathrm{g} / 100 \mathrm{~g})$ & $79.85 \pm 0.40$ & $70.56 \pm 0.10$ & $61.02 \pm 0.30$ & $55.15 \pm 0.30$ & $47.02 \pm 0.30$ \\
\hline Energy(Kcal/g) & $395.34 \pm 0.20$ & $416.99 \pm 0.20$ & $439.88 \pm 0.20$ & $446 \pm 0.10$ & $464.31 \pm 0.30$ \\
\hline
\end{tabular}

Table 2: Proximate composition of Blends of shelf stable maize starch and partially defatted beniseed meal using the solvent extraction method.

A: Shelf stable maize starch.

B: 87. 5: 12.5\% Maize starch to partially defatted Beniseed meal.

C: $75: 25 \%$ Maize Starch to partially defatted Beniseed meal \pm .

D: $62.5: 37.5 \%$ Maize starch to partially defatted Beniseed meal.

E: 50:50\% Maize starch to partially defatted Beniseed meal.

CHO: Carbohydrate.

\begin{tabular}{|l|c|c|c|c|c|}
\hline \multicolumn{1}{|c|}{ Parameters } & A & B & C & D & E \\
\hline Protein $(\mathrm{g} / 100 \mathrm{~g})$ & $5.47 \pm 0.20 \pm 0.20$ & $6.04 \pm 0.10$ & $11.23 \pm 0.10$ & $11.47 \pm 0.01$ & $15.87 \pm 0.01$ \\
\hline Fat $(\mathrm{g} / 100 \mathrm{~g})$ & $6.01 \pm 0.20$ & $9.39 \pm 0.10$ & $13.50 \pm 0.02$ & $21.06 \pm 0.02$ & $23.74 \pm 0.10$ \\
\hline Fiber $(\mathrm{g} / 100 \mathrm{~g})$ & $1.82 \pm 0.20$ & $2.19 \pm 0.20$ & $3.94 \pm 0.20$ & $4.51 \pm 0.10$ & $4.90 \pm 0.20$ \\
\hline Ash $(\mathrm{g} / 100 \mathrm{~g})$ & $0.62 \pm 0.10$ & $0.50 \pm 0.20$ & $1.00 \pm 0.20$ & $1.44 \pm 0.20$ & $2.00 \pm 0.10$ \\
\hline CHO $(\mathrm{g} / 100 \mathrm{~g})$ & $79.85 \pm 0.40$ & $71.88 \pm 0.20$ & $61.43 \pm 0.20$ & $52.33 \pm 0.30$ & $48.10 \pm 0.30$ \\
\hline Energy $(\mathrm{Kcal} / \mathrm{g})$ & $395.34 \pm 0.20$ & $396.19 \pm 0.20$ & $412.14 \pm 0.20$ & $444.74 \pm 0.20$ & $468.18 \pm 0.30$ \\
\hline
\end{tabular}

Table 3: Proximate composition of Blends of shelf stable maize starch and partially defatted beniseed meal using the hand press method. A: Shelf stable maize starch.

B: $87.5: 12.5 \%$ Maize starch to partially defatted Beniseed meal.

C: $75: 25 \%$ Maize Starch to partially defatted Beniseed meal.

D: $62.5: 37.5 \%$ Maize starch to partially defatted Beniseed meal.

E: 50:50\% Maize starch to partially defatted Beniseed meal.

CHO: Carbohydrate. 
Similar results were reported for cereal/legume fortifications by Eugenie., et al. [8], Jeanne., et al. [6], Anuonye., et al. [15,16], and Theobald and Mary [7]. However higher protein values were recorded for maize and sorghum flours and their corresponding blends are comparable with the present work. This can be attributed to the use of whole flours of these cereals as compared to the use of starch used in this study. On the other hand the protein content recorded in this work is significantly $(\mathrm{P}<0.05)$ higher than values reported by Jeanne., et al. [6] for complimented maize/legume porridges. The difference in the reported values may be connected to dilution effects during the preparations of the earlier samples into porridge.

The fat content of complemented samples increased from 6.01$75 \%$ for solvent defatted and from $6.01-78 \%$ for hand pressed defatted samples. The increases in fat content were expected due to the high oil content of sesame as reported by Pulseglove [17] to be in the range of 23 to $65 \%$. However apart from samples D and E, Eugenie., et al. [8] reported higher values of fat for full fat flours of heated and unheated marama beans/sorghum composite meals. Theobald and Mary [7] on the other hand reported lower values of fat for blends of maize, ground nut, germinated SUA- 90 beans and sugar blends. Though they reported that fat increased between $57-$ $177 \%$, actual values were significantly $(\mathrm{P}<0.05)$ lower than values reported in this work. The high oil content of the samples however met the FAO recommendation for growing and aged people as reported by Shatabdi [18]. Other beneficial aspects of increased dietary fats have been reported by Theobald and Mary [7].

The energy (kcal/g) content of the raw and complemented blends showed that energy values increased from $5-14 \%$ for sesame meal defatted using solvent while the increase was from $5-23 \%$ for the meal that was hand pressed. The little differences in the energy composition may be due to the slight higher fat values of the hand pressed meal. The energy values of the complemented samples met the requirement for complemented meals as they were above the $1.0 \mathrm{Kcal} / \mathrm{g}$ recommended by FAO/WHO (1985) for children aged 2-5years. Several authors [8]. Theobald and Mary [7], Jeanne., et al. [6] have reported similar increases in energy for complemented foods. Bintu., et al. [9] reported energy values of $67-68 \mathrm{kcal} / 100 \mathrm{~g}$ for white maize cowpea/ bambara groundnut/groundnut and yellow maize/ cowpea/groundnut/ bambara groundnut mixes. These values were significantly $(\mathrm{P}<0.05)$ lower than the values obtained for our complemented blends. However the energy values reported for Cerelac of $410 \mathrm{Kcal} / 100 \mathrm{~g}$ and 416 kcal $/ 100 \mathrm{~g}$ for Frisogold which are commercial blends [9] are closer to the values obtained for the partially defatted sesame and shelf stable maize starch blends. However, Roberts., et al. [19] reported higher values of $500 \mathrm{kcal}$ for maize- soya blend "plus plus"(MBS++) and ready-to-use supplementary food (RUSF) with 18.40 and 12.50 $(\mathrm{g} / 100 \mathrm{~g})$ protein and 11.60 and $32.90(\mathrm{~g} / 100 \mathrm{~g})$ fat respectively. The implication of the high energy values for the partially defatted sesame meal and shelf stable maize blends is that it will be suitable for high protein-energy composite meals.

The fibre content of the blends was within the 5/100g amount recommended by FAO (1985) codex committee for weaning foods. The values for fibre content of $2.19-4.51 \%$ were slightly higher than the $2.01-2.88 \%$ reported by Theobald and Mary [7] for maize and sorghum based diets, but significantly $(\mathrm{P}<0.05)$ lower than the 11-12\% reported by Bintu., et al. [9] for blends of Yellow and White maize varieties with cowpea/groundnut and bambara groundnut.

\section{Minerals}

There were significant differences in the mineral content of the blends as depicted in table 4 . The low level of calcium in the undefatted sample D is in agreement with previous reports by Rosaland., et al. [20] and Inyang and Ekanem [21] that beniseed contains appreciable level of oxalic acid of between 2-3\% which complexes with calcium and reduces its absorption and availability. The low values for the minerals tally with the low values of the ash content of the samples. Theobalb and Mary [7] and Bintu., et al. [9] reported that ash content of meals is an indication of the mineral density and other forms of contamination. Thus, the low ash content got from this work is, therefore, indicative of the blends low mineral concentrations. Bintu., et al. [9] reported similar low values for minerals particularly calcium, sodium and potassium for blends of fermented Yellow and White maize varieties with cowpea/groundnut and bambara groundnut. Thus, the low levels of these minerals may be attributed to loss in ash content during processing.

\begin{tabular}{|l|c|c|c|c|c|c|c|}
\hline Samples & \multicolumn{7}{|c|}{ Mineral Elements Evaluated (mg/100g) } \\
\hline & $\mathbf{P}$ & $\mathbf{K}$ & $\mathbf{N a}$ & $\mathbf{C a}$ & $\mathbf{M g}$ & $\mathbf{F e}$ & $\mathbf{C u}$ \\
\hline $\mathrm{A}$ & $0.37^{\mathrm{a}}$ & $0.35^{\mathrm{a}}$ & $1.69^{\mathrm{a}}$ & $0.14^{\mathrm{a}}$ & $0.14^{\mathrm{b}}$ & $5.50^{\mathrm{a}}$ & $0.00^{\mathrm{b}}$ \\
\hline $\mathrm{B}$ & $0.29^{\mathrm{b}}$ & $0.07^{\mathrm{c}}$ & $1.08^{\mathrm{c}}$ & $0.05^{\mathrm{c}}$ & $0.32^{\mathrm{a}}$ & $2.51^{\mathrm{b}}$ & $0.51^{\mathrm{a}}$ \\
\hline $\mathrm{C}$ & $0.30^{\mathrm{a}}$ & $0.18^{\mathrm{b}}$ & $1.31^{\mathrm{b}}$ & $0.10^{\mathrm{b}}$ & $0.14^{\mathrm{b}}$ & $4.51^{\mathrm{ab}}$ & $0.00^{\mathrm{b}}$ \\
\hline D & $0.33^{\mathrm{a}}$ & $0.16^{\mathrm{b}}$ & $1.45^{\mathrm{a}}$ & $0.10^{\mathrm{b}}$ & $0.05^{\mathrm{c}}$ & $4.51^{\mathrm{b}}$ & $0.00^{\mathrm{a}}$ \\
\hline
\end{tabular}

Table 4: Mineral composition of raw and blended samples.

A: Raw beniseed.

B: Shelf Stable Maize starch.

C: $62.5: 37.5 \%$ Shelf Stable maize Starch to partially defatted sesame meal using solvent extraction.

D: $62.5: 37.5 \%$ Shelf Stable maize Starch to partially defatted sesame meal using hand press extraction method. 


\section{Amino acids}

The results of Amino Acid Profile (AAP) of the raw and blended samples are shown in table 5. The results show that maize starch was significantly $(\mathrm{P}<0.05)$ deficient in nearly all the evaluated amino acids confirming the earlier report by Akanbi., et al. [2] that infants adolescents and adults subjected to regimes of maize starch meal may not receive adequate nourishment leading to malnutri- tion especially of the protein - energy type or kwashiorkor. The addition of beniseed meal up to $37.5 \%$ in this study must have resulted in adequate compensation of the deficiencies noticed in maize starch amino acid profile for all cadres of users. The results show that the amnio acids exceeded the minimum recommendations by FAO/WHO (1985). Substitution of beniseed meal at 37.5\% also resulted in meeting the requirements for sulphur amino acids which are the limiting amino acid in similar other oilseeds and legumes.

\begin{tabular}{|l|c|c|c|c|c|c|c|}
\hline & \multicolumn{5}{|c|}{ Samples (g/100g protein) } & \multicolumn{2}{c|}{ FAO Recommendation (g/100g protein) } \\
\hline \multicolumn{1}{|c|}{ Amino acids } & A & B & C & D & Children & Adolescence & Adult \\
\hline Lysine & 2.85 & 2.56 & 2.60 & 0.05 & 5.2 & 4.8 & 4.5 \\
\hline Histidine & 2.76 & 2.56 & 2.60 & 0.09 & 1.8 & 1.6 & 1.5 \\
\hline Arginine & 11.32 & 7.66 & 8.25 & 0.17 & - & & \\
\hline Aspartic acid & 8.35 & 8.10 & 8.15 & 0.25 & - & & 2.3 \\
\hline Threonine & 3.35 & 3.08 & 3.20 & 0.11 & 2.7 & 2.5 & \\
\hline Serine & 3.16 & 3.00 & 3.01 & 0.16 & - & & \\
\hline Glutamic acid & 17.36 & 16.02 & 16.69 & 0.74 & - & & \\
\hline Proline & 5.10 & 4.25 & 4.78 & 0.32 & - & & \\
\hline Alanine & 4.22 & 4.10 & 4.15 & 0.23 & - & & \\
\hline Cystine & 2.05 & 1.52 & 1.79 & 0.70 & - & & \\
\hline Valine & 4.71 & 4.30 & 4.42 & 0.17 & 4.2 & 4.0 & 3.0 \\
\hline Methionine & 2.94 & 1.88 & 2.19 & 0.80 & - & & 5.9 \\
\hline Isoleucine & 3.39 & 3.20 & 3.25 & 0.13 & 3.1 & & \\
\hline Leucine & 7.38 & 7.20 & 7.29 & 0.49 & 6.3 & 6.0 & \\
\hline Tyrosine & 3.86 & 3.70 & 3.70 & 0.17 & - & & \\
\hline Phenylalanine & 4.14 & 4.00 & 4.00 & 0.17 & - & & \\
\hline
\end{tabular}

Table 5: Amino Acid Profile of Raw and Blended Samples Compared with FAO Standard.

Key: A: Raw beniseed; B: 62.5: 37.5\% of Maize Starch to defatted beniseed meal solvent Extraction; C: 62.5: 37.5\% of Maize Starch to hand pressed partially defatted beniseed meal; D: Maize starch FAO (1985): Standard requirements for Amino acid.

Looking at the chemical score which is one method of estimating the quality of amino acids, table 6 shows that the limiting amnio acid in the amino acid profile of sesame meal was lysine while at the same time maize starch was limited in all essential amino acids. The poor quality of maize starch amino acids has been previously noted by Akanbi., et al. [2], as a major limitation to its use for weaning purposes thus making complementation a necessary imperative.

Jeanne., et al. [6] reported that in blends of maize with processed groundnut paste or maize and processed beans though significant $(\mathrm{P}<0.05)$ increases were recorded in the amino acid profile, the protein chemical scores remained below the recommended value of 1.00 by FAO (1999). The complementation of maize starch with meals of partially defatted sesame meal however presented a contrast.

Jean., et al. [6] also reported that despite the significant $(\mathrm{P}<$ 0.05 ) increases in amino acid of blends of fermented maize and germinated groundnuts and fermented maize and roasted groundnuts and fermented maize and germinated beans, the chemical score of these blends were below the recommended value of 1.0 indicating that all the essential amino acids were not satisfactorily met. Though we did not record exactly the recommended value 1.0 in all the essential amino acids in this current work, the results show that the chemical scores of our blends were superior to those of the earlier reports. The hand pressed manual method of defatting can easily be adopted for house - hold preparations which will add value to beniseed usage at that level.

\section{Anti nutrient composition}

The results of the anti nutrient composition of the samples are shown in table 7 . The results show that defatting irrespective of the method used resulted in significant $(\mathrm{P}<0.05)$ lowering of the evaluated anti nutrients. As expected undefatted beniseed meals recorded higher levels of antinutrients as previously reported by Inyang and Eknem [21]. The results are also in agreement with earlier 


\begin{tabular}{|l|c|c|c|c|c|c|c|c|c|c|c|}
\hline \multicolumn{1}{|c|}{ Amino acids } & \multicolumn{10}{c|}{ Samples } \\
\hline EAA & $\mathrm{A}$ & $\mathrm{A}^{\mathrm{I}}$ & $\mathrm{B}$ & $\mathrm{B}^{\mathrm{I}}$ & $\mathrm{C}$ & $\mathrm{C}^{\mathrm{I}}$ & $\mathrm{D}$ & $\mathrm{D}^{\mathrm{I}}$ & $\mathrm{E}$ & $\mathrm{F}$ & $\mathrm{G}$ \\
\hline Histidine & 2.76 & 1.45 & 2.56 & 1.34 & 2.60 & 1.36 & 0.09 & 0.04 & 1.8 & 1.5 & 1.90 \\
\hline Trptophan & - & - & - & - & - & - & - & - & - & - & 1.40 \\
\hline Threonine & 3.35 & 0.99 & 3.08 & 0.91 & 3.20 & 0.94 & 0.11 & 0.03 & 2.7 & 2.3 & 3.40 \\
\hline Valine & 4.70 & 1.34 & 4.30 & 0.97 & 4.42 & 1.26 & 0.17 & 0.05 & 4.2 & 4.0 & 3.50 \\
\hline Methionine+Cystiene & 2.94 & 1.18 & 1.88 & 0.75 & 2.60 & 1.04 & 1.50 & 0.60 & - & - & 2.50 \\
\hline Isoleucine & 3.39 & 1.21 & 3.20 & 1.14 & 3.25 & 1.16 & 0.13 & 0.05 & 3.1 & 3.0 & 2.80 \\
\hline Leucine & 7.38 & 1.12 & 7.21 & 1.09 & 7.29 & 1.10 & 0.49 & 0.07 & 6.3 & 5.9 & 6.60 \\
\hline Phenyl alanine+ Tryosine & 8.00 & 1.27 & 7.70 & 1.22 & 7.70 & 1.22 & 0.34 & 0.05 & - & -- & 6.30 \\
\hline Lysine & 2.85 & 0.49 & 2.50 & 0.43 & 2.60 & 0.52 & 0.05 & 0.01 & 5.2 & 4.5 & 5.80 \\
\hline Total amino acids/ score & & 9.05 & & 7.85 & & 8.58 & & 0.36 & & & $\geq 6.50$ \\
\hline Limiting AA & Lysine & 0.49 & Lysine & 0.43 & Lysine & 0.52 & Lysine & 0.01 & & & \\
\hline
\end{tabular}

Table 6: Essential Amino Acids, chemical score of beniseed meal maize starch and blended Samples compared to FAO /WHO reference Amino Acid (1985).

Key

A: Amino acid profile of Raw beniseed.

$\mathrm{A}^{\mathrm{I}}$ : Chemical score of sample A.

B: Amino acid profile of $62.5: 37.5 \%$ of Maize Starch and defatted beniseed meal solvent Extraction.

$\mathrm{B}^{\mathrm{I}}$ : Chemical score of sample B.

C: $62.5: 37.5 \%$ of Maize Starch to hand pressed partially defatted beniseed meal.

Cl: Chemical score of sample C.

D: Amino acid profile of Maize starch $\mathrm{D}^{\mathrm{I}}=$ Chemical score of Maize Starch.

E and F: FAO (1985) Standard chemical score requirements for infants and adults.

G: Recommended Totals.

earlier reports on cereal/oilseeds complementation [15,20,22]. Anuonye [16] had earlier on attributed reduction in anti nutrient values to dilution effects as the result of blending and other processing steps.

\begin{tabular}{|l|c|c|c|}
\hline Samples & \multicolumn{3}{|c|}{ Antinutrients } \\
\hline & Oxalate & Pytate & Tannins \\
\hline A & $6.06 \pm 0.12^{\mathrm{a}}$ & $4.01 \pm 0.28^{\mathrm{a}}$ & $2.50 \pm 0.21^{\mathrm{a}}$ \\
\hline $\mathrm{B}$ & $1.57 \pm 0.12^{\mathrm{b}}$ & $1.11 \pm 0.28^{\mathrm{b}}$ & $1.25 \pm 0.21^{\mathrm{b}}$ \\
\hline C & $1.31 \pm 0.28^{\mathrm{b}}$ & $0.17 \pm 0.21^{\mathrm{c}}$ & $0.20 \pm 0.28^{\mathrm{c}}$ \\
\hline D & $1.37^{\mathrm{a}} \pm 0.07^{\mathrm{b}}$ & $0.19^{\mathrm{a}} \pm 0.40^{\mathrm{c}}$ & $0.28 \pm 0.17^{\mathrm{c}}$ \\
\hline
\end{tabular}

Table 7: Anti nutrient composition of blends of maize Starch and hand pressed and solvent defatted beniseed flour meal

$(\mathrm{Mg} / 100 \mathrm{~g})$.

A: Raw beniseed; B: Shelf Stable Maize starch; C: $62.5: 37.5 \%$ Shelf Stable maize Starch to partially defatted sesame meal using solvent extraction; D: 62.5:37.5\% Shelf Stable maize Starch to partially defatted sesame meal using hand press extraction method.

\section{Acceptability}

The sensory evaluation results on the pap resulting from this study are presented in tables 8 and 9 for both methods of defat- ting. The results show that sole maize meal had significant $(\mathrm{P}<$ 0.05 ) higher scores in all parameters tested than sample blends. However samples at lower levels of beniseed flour meal substitution of 12.5 and $37.5 \%$ were not significantly $(\mathrm{P}<0.05)$ rated lower than the sole maize meal. Blends from mixtures of partially defatted beniseed prepared by hand pressing method were preferred to sample blends prepared from meals of chemical extraction by the panelists. The reason for this may not be unconnected with the perception of the residual odour of the hexane used for the extraction. Sample blends of $12.5 \%$ and $37.5 \%$ sesame seed flour meals commanded over 70\% acceptance. Anuonye [3] recorded similar levels of acceptance for sesame flour meals and wheat flour in composite bread roll formula. As expected, acceptability decreased with increasing levels of sesame flour meal substitution in the blends from the present study. This must have been due to the perception of the inherent bitterness in sesame oil meal which may have influenced the panelist in their rankings $[23,24]$.

\section{Conclusion and Recommendations}

The results of this work show that defatted sesame flour can be used to supplement shelf stable maize starch for the development of weaning and convenient meals. The samples containing 37.50\% of defatted beniseed meals recorded appreciable levels of protein and fat. The mineral analysis shows that phosphorus, potas- 


\begin{tabular}{|l|c|c|c|c|c|c|c|}
\hline Parameters & Appearance & Aroma & Colour & Evenness & Taste & Texture & Overall Accept \\
\hline A & $8.00^{\mathrm{a}}$ & $6.41^{\mathrm{a}}$ & $7.17^{\mathrm{a}}$ & $6.75^{\mathrm{a}}$ & $6.75^{\mathrm{a}}$ & $7.50^{\mathrm{a}}$ & $7.20^{\mathrm{a}}$ \\
\hline B & $7.80^{\mathrm{a}}$ & $6.42^{\mathrm{a}}$ & $7.08^{\mathrm{a}}$ & $6.58^{\mathrm{a}}$ & $6.83^{\mathrm{a}}$ & $7.17^{\mathrm{a}}$ & $6.89^{\mathrm{a}}$ \\
\hline C & $7.17^{\mathrm{a}}$ & $6.67^{\mathrm{a}}$ & $6.83^{\mathrm{a}}$ & $6.58^{\mathrm{a}}$ & $6.08^{\mathrm{a}}$ & $7.00^{\mathrm{a}}$ & $6.70^{\mathrm{a}}$ \\
\hline D & $6.92^{\mathrm{a}}$ & $6.58^{\mathrm{a}}$ & $6.58^{\mathrm{a}}$ & $6.67^{\mathrm{a}}$ & $6.42^{\mathrm{a}}$ & $6.67^{\mathrm{a}}$ & $6.30^{\mathrm{a}}$ \\
\hline E & $6.33^{\mathrm{a}}$ & $5.92^{\mathrm{a}}$ & $6.00^{\mathrm{a}}$ & $5.75^{\mathrm{a}}$ & $5.42^{\mathrm{a}}$ & $6.00^{\mathrm{a}}$ & $5.12 \mathrm{a}$ \\
\hline
\end{tabular}

Table 8: Mean sensory score of blends of maize starch and solvent defatted beniseed.

Values are means of three determinations.

Values with the same superscript along the same column are not significantly different $(\mathrm{p} \geq 0.05)$

\begin{tabular}{|l|c|c|c|c|c|c|c|}
\hline Parameters & Appearance & Aroma & Colour & Evenness & Taste & Texture & Overall Accept \\
\hline A & $8.42^{\mathrm{a}}$ & $7.42^{\mathrm{a}}$ & $7.74^{\mathrm{a}}$ & $7.89^{\mathrm{a}}$ & $7.68^{\mathrm{a}}$ & $8.12^{\mathrm{a}}$ & $7.42^{\mathrm{a}}$ \\
\hline B & $7.26^{\mathrm{b}}$ & $7.16^{\mathrm{b}}$ & $7.37^{\mathrm{a}}$ & $7.53^{\mathrm{a}}$ & $7.16^{\mathrm{b}}$ & $7.42^{\mathrm{b}}$ & $7.06^{\mathrm{b}}$ \\
\hline C & $7.16^{\mathrm{b}}$ & $7.05^{\mathrm{b}}$ & $7.37^{\mathrm{a}}$ & $7.00^{\mathrm{b}}$ & $7.11^{\mathrm{b}}$ & $7.37^{\mathrm{b}}$ & $7.11 \mathrm{~b}^{\mathrm{a}}$ \\
\hline D & $6.47^{\mathrm{c}}$ & $7.11^{\mathrm{b}}$ & $6.63^{\mathrm{b}}$ & $6.42^{\mathrm{b}}$ & $6.58^{\mathrm{b}}$ & $6.53^{\mathrm{c}}$ & $6.48^{\mathrm{c}}$ \\
\hline E & $5.79^{\mathrm{d}}$ & $6.47^{\mathrm{c}}$ & $6.05^{\mathrm{c}}$ & $6.05^{\mathrm{c}}$ & $6.11^{\mathrm{c}}$ & $5.79^{\mathrm{d}}$ & $6.00^{\mathrm{d}}$ \\
\hline
\end{tabular}

Table 9: Mean sensory score of blends of maize starch and solvent defatted beniseed.

Values are means of three determinations.

Values with the same superscript along the same column are not significantly different $(p \geq 0.05)$

Key
A: Control (100\% Maize starch).
B: Blends of maize starch and solvent defatted beniseed flour meal (87.50:12.50\%).
C: Blends of maize starch and solvent defatted beniseed flour meal (75.00: 25.00\%).
D: Blends of maize starch and solvent defatted beniseed flour meal (62.50:37.50\%).
E: Blends of maize starch and solvent defatted beniseed flour meal (50.00:50.00\%).

sium and iron were slightly higher in the complemented samples than the shelf stable maize starch. The Amino acid shows that the supplementation of maize starch with beniseed flour at $37.50 \%$ for the development of convenient food will produce nutritionally adequate meal which meets the FAO nutritional requirement for children, adolescent and adults in nearly all the amino acids with balanced chemical score. The blends are also superior to earlier reported blends. It is, therefore, believed that the blending of maize starch and defatted beniseed flour up to $37.50 \%$ levels of substitution will improve the nutrient composition of the composite meal. This will provide cheap, affordable and sustainable source of convenient and weaning diets with high energy and protein density. It is, therefore, recommended that the pasting viscosity and keeping quality of the product be evaluated for speedy adoption.

\section{Bibliography}

1. Faber M., et al. "Nutritional status and dietary intakes of children aged 2-5 years and their caregivers in a rural South African community". International Journal Food Science Nutrition 52 (2001): 401-411.
2. Akanbi CT., et al. "Effect of processing factors on rheological properties of Ogi". International Journal of Food Properties 6 (2003): 405-418.

3. Anuonye JC., et al. "Development of shelf-stable cereal starches for weaning purposes". Book of Abstract, 5th National Universities Commission Research and Development Fair, Federal University of Technology Minna Nigeria (2012): 9-10.

4. Egounlety., et al. "Nutritional and sensory evaluation of tempe-fortified maize-based weaning foods". International Journal of Food Science and Nutrition 53 (2002): 15-27.

5. Uwala AC. Common field pest and disease of Beniseed and their control: in training manual on Benissed production technology organized by FDA/ NCRI under the NACPP and ARTP June 4-7 (2002): 16-17.

6. Jeanne., et al. "Improvement of the nutritional quality of traditional complementary porridge made of fermented yellow maize (Zea mays): Effect of maize-legume combinations and traditional processing methods". Food and Nutrition Bulletin 28 (2007): 23-34. 
7. Theobald CE Mosha and Mary M Vicent. "Nutritional quality, storage stability and acceptability of home-processed readyto eat composite foods for rehabilitating undernourished preschool children in low- income countries". Journal of food processing and preservation 29 (2005): 331-356.

8. Eugenie., et al. "Nutritional quality and antioxidant activity of marama-sorghum composite flours and porridges". Food Chemistry 131 (2012): 837-842.

9. Bintu BP., et al. "Studies on the evaluation of nutritional quality chemical composition and rheological characteristics of a cereal fortified with legume as a weaning food blend". International Journal of Biotechnology and Food Science 3 (2015): 1-9.

10. Anuonye JC., et al. "Preliminary studies on the characterization of 17 varieties of beniseed based on processing parameters". Nigerian Institution of Food Science and Technology (NIFST) Annual Conference Proceedings (1999): 256-258.

11. Nwabueze TU and Iwe MO. "Residence time distribution (RTD) in a single screw Extrusion of Africa breadfruit mixture". Food Bioprocess Technology 3 (2010): 135-145

12. Anuonye JC. "Effects of extrusion process variables on the physico-chemical, sensory, microbial and storage properties of product from acha (Digitaria exilis) and soybean (Glycine max L. Merill)". Ph.D Thesis, University of Agriculture Makurdi (2006).

13. AOAC. Official Method of Analysis. Association of Official Analytical Chemist. W. Horwitz (Ed) Washington, D.C (2012).

14. Spackman DH., et al. "Automatic recording apparatus for use in chromatography of amino acids". Analytical chemistry 30 (1958): 1185-1190.

15. Anuonye JC., et al. "Nutrient and anti nutrient composition of extruded acha/soybean blends". Journal of Processing and Preservation 34 (2009): 680-691.

16. Anuonye JC. "Effect of blending and extrusion on the physicochemical nutritional and microbial quality of acha/soybeans mixtures". Journal of Science and Technology 16 (2010): 85-95.

17. Pulseglove JW. "Tropical Crops: Monocotyledons vol 1 and 2 combined". English Longman (1975): 142-143.

18. Shatabdi Goon. "Dietary inclusion of palm Oil in Bangladeshi Dietensures .Better nutrition with minimal cost: an overview". Journal of Food Technology Research 1 (2014): 21-26.

19. Robert S., et al. "Malian children with acute malnutrition who are treated with lipid -based dietary supplements have greater weight gains and recovery rates than those with locally produced cereal-legume products: a community-based cluster-randomized trial". American Journal of Clinical Nutrition 101 (2015): 632-645.
20. Rosalind S., et al. "Improving the bioavailability of nutrients in plant foods at the household level". Proceedings of the Nutrition Society 65 (2006): 160-168.

21. Inyang UE and Ekanem IO. "Effect of dehulling methods and desolventizing temperatures on proximate composition and some functional properties of sesame (Sesamum Indicum L.) seed flour". Journal of American Oil Chemist's Society 73 (1996): 1133-1136.

22. Iwe MO. "The Science and Technology of Soybean: Chemistry Nutrition Processing and Utilization". 1st Edtion. Rejoint communication Services Ltd. Uwani, Enugu Nigeria (2003).

23. Aminigo ER and Akingbala JO. "Nutritive composition and sensory properties of ogi fortified with okra seed meal". Journal of Applied Science Environmental Management 8 (2004): 23-28.

24. Fagbemi TN., et al. "Effect of processing and salt on some functional properties of cashew nut (Anarcadium Occidentalis) flour". Food, Agriculture and Environment 12 (2004): 121-128.

\section{Volume 3 Issue 11 November 2019 (C) All rights are reserved by Wada AC., et al.}

